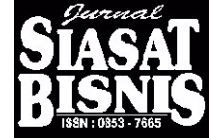

Hal: 43-59

\title{
MODEL INTEGRASI LINGKUNGAN BISNIS - STRATEGI OPERASI - KINERJA PERUSAHAAN, STUDI EMPIRIS PADA PERUSAHAAN MANUFAKTUR MENENGAH BESAR DI TASIKMALAYA
}

\author{
Edy Suroso \\ Fakultas Ekonomi, Universitas Siliwangi Tasikmalaya \\ e-mail:edysuroso78@yahoo.com
}

\begin{abstract}
This research is to develop a theoretical model about performance and to test the influence of business environment in determining operations strategy and to improve company performance by empirical test in high medium manufacturing company in Tasikmalaya.This is explanatory research. The method of the research is survey. The object of the research consists of business environment, operations strategy and performance. The research location is in Tasikmalaya City and Regency involving the high medium manufacturing companies. The research subject is CEO. The research population is 192 high medium manufacturing companies in Tasikmalaya. The research sample is 110 companies determined by Structural Equation Model, as the method of analysing data, which is operated by AMOS. The conclusions of the research are: (1) Business environment sets a significant role in determining operations strategy choice, so to decide the competitive company priority needs the right identified scanning environment. (2) The success of the company in uncertainty business condition will be reached if the company is able to focus itself in cost strategy, quality strategy and delivery strategy.
\end{abstract}

Keywords:business environment, operations strategy, performance and balance score card

\section{PENDAHULUAN}

Studi empiris menemukan bahwa keberhasilan perusahaan dalam mencapai kinerja yang efektif ditentukan oleh perumusan kebijakan strategis perusahaan oleh manajer (Ghofar, 2004). Schroeder et. al. (1986) dan Swamidass (1986) menemukan bahwa pemahaman manajer terhadap strategi operasi sangatlah minim. Selama ini proses implementasi strategi operasi dalam perusahaan sering diartikan sebagai aktivitas rutin, standar, dan tidak menggairahkan, manufaktur hanya bertumpu pada teknologi, strategi fleksibilitas dan pencapaian efisiensi (biaya), atau lebih bersifat teknis dan otomatis.
Paradigma tersebut menyebabkan tidak adanya sebuah dialektika manufaktur yang menantang manajer untuk berkecimpung dalam perusahaan. Elliyanti (1990) mengungkapkan bahwa manufacturing kurang mengundang minat orangorang berbakat dan mempunyai kemampuan serta minat besar terhadap manajemen. Permasalahan tersebut hanya dapat diatasi melalui mekanisme yang menggabungkan proses manufaktur dan strategi perusahaan. Fenomena ini menunjukkan bahwa penerapan ekonomi normatif tidak bisa dilakukan secara sekuler melainkan dengan menggunakan pendekatan komprehensif dan sinergis (Ghofar, 2004). 
Hasil penelitian Ellitan (2001) dengan mengambil sampel perusahaan manufaktur skala besar di Indonesia menunjukkan bahwa faktor-faktor lingkungan bisnis mempengaruhi pilihan strategi operasi. Berbagai penelitian tentang kontribusi strategi operasi terhadap peningkatan kinerja perusahaan telah dilakukan oleh beberapa peneliti. Ghofar (2004) menguji pengaruh strategi operasi terhadap kinerja dengan mengambil sampel perusahaan manufaktur skala menengah besar di Yogyakarta. Hasil penelitiannya menunjukkan bahwa strategi operasi secara simultan dan parsial mempunyai pengaruh terhadap kinerja perusahaan baik kinerja keuangan maupun kinerja manufaktur.

Peneliti ingin mengembangkan model integrasi lingkungan bisnis, strategi operasi, dan kinerja perusahaan. Hal ini dikarenakan penelitian yang dilakukan Ellitan (2001) hanya menguji pengaruh lingkungan bisnis terhadap strategi operasi, sedangkan penelitian Ghofar (2004) hanya menguji model pengaruh strategi operasi terhadap kinerja perusahaan. Research gap tersebut menjadi alasan utama bagi peneliti untuk mengintegrasikan kedua penelitian tersebut. Berdasarkan uraian yang telah dikemukakan, maka masalah pokok (research problem) dalam penelitian ini adalah: "Bagaimana model integrasi lingkungan bisnis, strategi operasi dan kinerja perusahaan diimplementasikan pada perusahaan manufaktur skala menengah besar di Tasikmalaya?"

\section{KAJIAN PUSTAKA Lingkungan Bisnis}

Hasil studi teoritik dan kajian empiris dari beberapa ahli telah mengelompokkan lingkungan secara berbeda-beda. Kerangka kerja konseptual untuk dimensi-dimensi lingkungan telah dikembangkan dalam literatur manajemen oleh Dess dan Beard (1984); Sharfanan dan Dean (1991) dikutip dalam Badri dan Davis (2000). Dimensidimensi lingkungan meliputi environmental munificence, environmental dynamism, dan environmental complexity.

Environmental munificence merupakan tingkat dukungan lingkungan terhadap pertumbuhan organisasi yang ada di dalamnya. Munificence seringkali diukur dengan tiga skala yang secara konseptual yaitu biaya melakukan produksi, ketersediaan tenaga kerja, dan tingkat persaingan. Ketersediaan tenaga kerja mewakili fokus pada pengurangan teknisi, clerical, dan pekerja produksi. Sedangkan competitive hostility (tingkat persaingan) mencakup fokus pada penurunan permintaan baik dalam pasar lokal maupun pasar asing dan fokus pada profit margin yang rendah dan standar kualitas permintaan.

Environmental dynamism (dinamisme lingkungan) mewakili kondisi perubahan lingkungan yang tidak dapat diprediksi (Dess dan Beard, 1984 dikutip dalam Ward, Bickford, dan Leaong, 1995). Lingkungan yang dinamis dikarakteristisasikan oleh perubahan lingkungan cepat dan kontinyu dalam hal permintaan, pesaing, teknologi, dan peraturan seperti informasi yang tidak akurat, tidak tersedia, dan ketinggalan jaman. Dinamisme lingkungan mengukur tingkat produk dan jasa dalam proses, dan tingkat perubahan selera, serta preferensi konsumen. Sedangkan environmental complexity merujuk pada homogenitasheterogenitas dan konsentrasi-penyebaran dari lingkungan yang membutuhkan persyaratan produksi yang berbeda untuk segmen pasar dan tingkat persaingan yang berbeda.

\section{Strategi Operasi}

Krawjesky dan Ritzman (2002) mendifinisikan strategi operasi sebagai dimensi yang harus dimiliki oleh sistem produksi suatu perusahaan untuk mendukung permintaan pasar agar perusahaan tersebut 
mampu bersaing. Sistem produksi adalah wahana yang dipakai dalam mengubah masukan (input) sumberdaya untuk menciptakan barang dan jasa yang bermanfaat (Buffa, 1994). Sedangkan Flahtery (1996) mendifinisikan strategi operasi sebagai papan rencana perusahaan atau unit bisnis untuk mengembangkan, memperkenalkan, dan menghasilkan produk agar memuaskan kebutuhan pelanggan lebih baik dari pesaing. Kedua difinisi tersebut memuat adanya orientasi pada pelanggan dan senjata bersaing.

Strategi operasi telah menjadi perhatian dalam bidang manajemen produksi/ operasi dan manajemen strategi sejak beberapa decade yang lalu (Skiner, 1969). Schroeder, Anderson, dan Cleveland (1986) menyatakan bahwa strategi operasi adalah program jangka panjang dari fungsi-fungsi manufaktur untuk memadukan strategi perusahaan secara keseluruhan. Beberapa studi mengeksplorasi strategi operasi dari diversifikasi perspektif untuk perencanaan strategi. Sweeney (1991) menganggap strategi operasi merupakan area khusus dari manajemen strategi. Cerwin (1993) menyimpulkan bahwa konsep dan definisi strategi operasi sebagai sebuah prosedur pengambilan keputusan perusahaan agar memiliki kepemimpinan dalam aktivitas manufacturing yang didasarkan pada persfektif strategi.

Dimensi strategi operasi sebagaimana dikemukakan Chase, et. al. (2001), Schroeder (2000), dan Ward, et. al. (1998) dapat dikelompokkan menjadi empat yaitu: biaya, kualitas, fleksibilitas, dan pengiriman. Keempat dimensi strategi tersebut bukanlah strategi yang saling meniadakan satu sama lain, tetapi merupakan satu kesatuan yang terpadu dan saling memperkuat. Stonebraker dan Leong (1994) mendifinisikan strategi biaya sebagai produksi dan distribusi sebuah produk dengan biaya terendah dan sumber daya tersisa (waste resources) yang minimum. Strategi ini mencerminkan prioritas perusahaan pada efisiensi biaya agar mampu berkompetisi berbasis pada biaya Strategi kualitas didefinisikan sebagai aktivitas perusahaan untuk memproduksi produk yang sesuai dengan spesifikasi atau memenuhi kebutuhan konsumen. Strategi pengiriman didefinisikan sebagai keandalan dalam memenuhi jadwal pengiriman yang diminta dan dijanjikan, atau kecepatan dalam merespon pemesanan konsumen. Sedangkan strategi fleksibilitas didefinisikan sebagai kemampuan untuk merespon perubahan cepat dalam produk, jasa dan proses.

\section{Kinerja Perusahaan}

Diversitas ukuran kinerja melalui ukuran finansial dan ukuran non finansial mampu memberikan penilaian yang lebih realistis disamping berfungsi sebagai pendorong (drivers) kinerja dimasa yang akan datang (Kaplan \& Norton, 1997; Scott \& Tiesen, 1999; Horngren, 2002). Esensi penggunaan alat pengukuran kinerja itu tergantung dari kesesuaian dengan tujuan yang diharapkan perusahaan dari hasil pengukuran kinerja tersebut. Alasan penggunaan kombinasi pengukuran kinerja adalah organisasi ataupun perusahaan, dalam lingkungan persaingan seperti sekarang ini, tidak dapat bergantung sepenuhnya kepada pengukur kinerja finansial yang fokusnya sempit. Pengukuran kinerja yang beragam akan melindungi pemilik perusahaan dari manajemen yang tidak dapat menyesuaikan diri dengan pasar (Berger 1997). Pendapat Berger sejalan dan konsisten dengan yang diungkapkan oleh Kaplan dan Norton (1996) tentang Balance Score Card (BSC).

Hasil studi tersebut menyimpulkan bahwa untuk mengukur kinerja eksekutif masa depan, diperlukan ukuran yang komprehensif yang mencakup empat perspektif: keuangan, pelanggan, proses bisnis/intern, 
dan pembelajaran dan pertumbuhan. Ukuran ini disebut dengan balanced scorecard. Berdasarkan pendekatan balanced scorecard, kinerja keuangan yang dihasilkan oleh eksekutif harus merupakan akibat diwujudkannya kinerja dalam pemuasan kebutuhan pelanggan, pelaksanaan proses bisnis/intern yang produktif dan cost effective, dan/atau pembangunan personel yang produktif dan berkomitmen.

\section{Kerangka Pemikiran dan Hipotesis}

Kerangka pemikiran dalam penelitian ini disajikan dalam Gambar 1 dan pengembangan model pada penelitian ini dapat disajikan seperti pada Gambar 2.

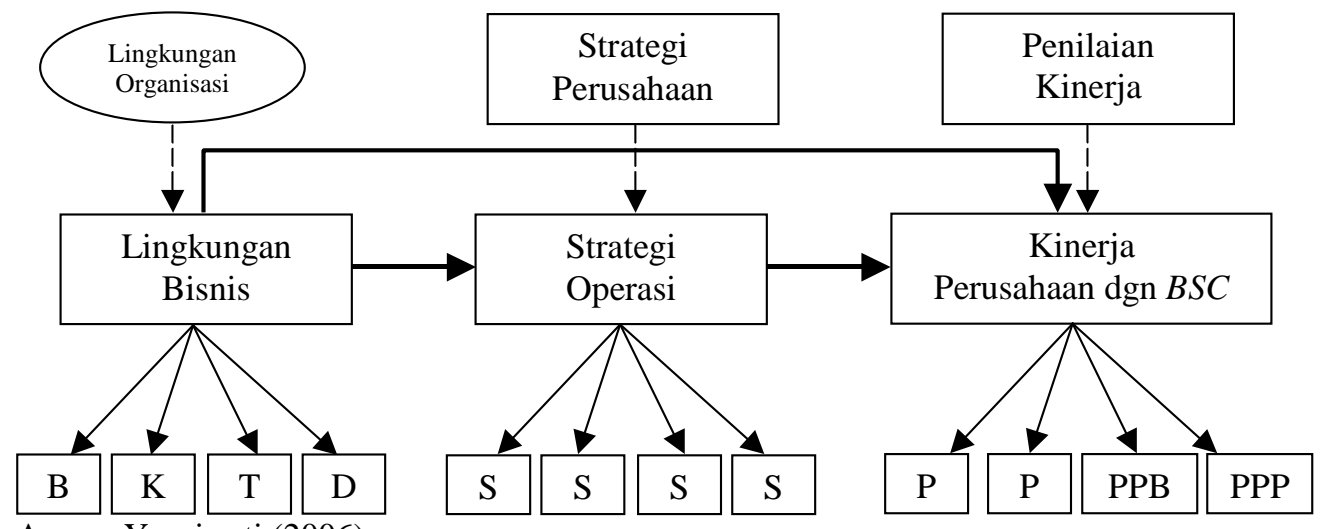

Acuan: Yurniwati (2006)

Gambar 1: Kerangka Pemikiran

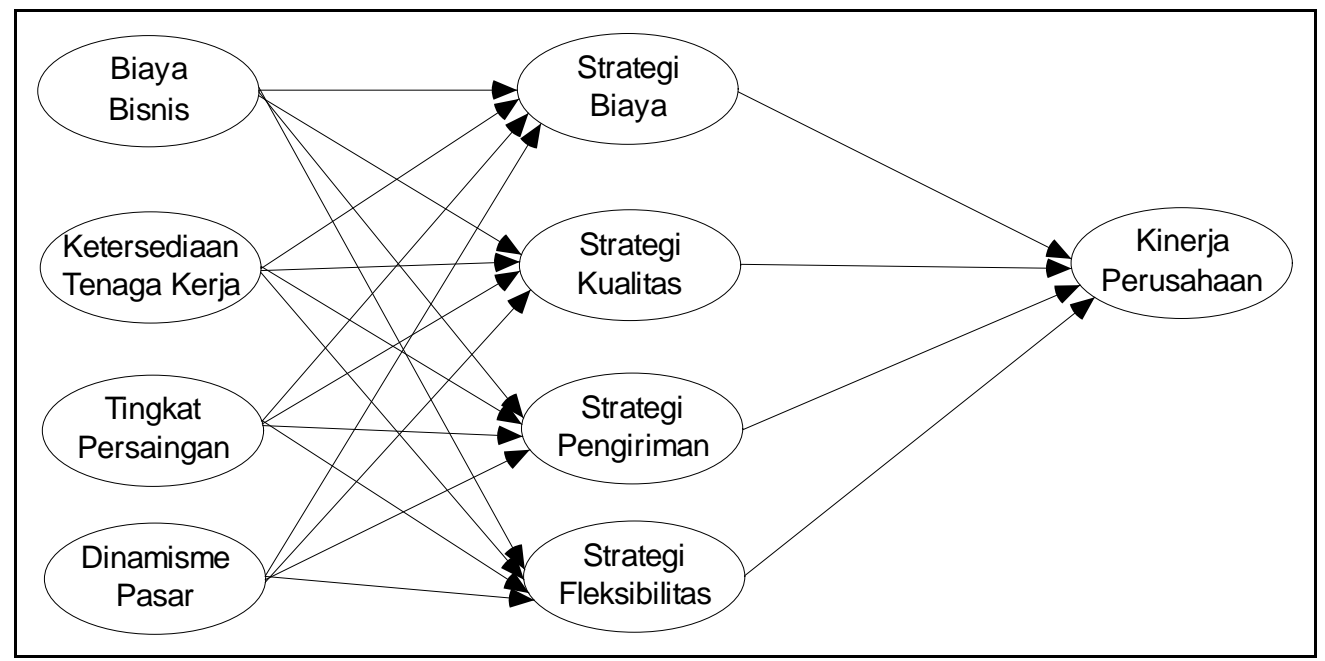

Acuan: Vananay dan Zulkarnain (2006)

Gambar 2: Pengembangan Model Penelitian 
Kesuksesan suatu perusahaan harus memiliki strategi yang cocok dengan lingkungan operasinya atau perusahaan harus mampu memanfaatkan lingkungannya untuk mendapatkan keunggulan melalui pemilihan strateginya. Beberapa perusahaan mengalami kegagalan pada saat strategi yang diambilnya tidak cocok lagi dengan lingkungan operasinya. Hill dan Jones (1995) menyatakan bahwa strategi kompetitif merupakan mediator penting yang mempengaruhi respon strategik perusahaan terhadap lingkungan baru.

Swamidas dan Newel (1987) memandang strategi operasi sebagai kekuatan manufaktur yang efektif sebagai satu senjata kompetitif untuk mencapai tujuan bisnis perusahaan. Strategi operasi mempengaruhi tujuan dan strategi bisnis serta memungkinkan fungsi manufaktur untuk memberikan kontribusi dalam meningkatkan daya saing perusahaan dalam jangka panjang (Wheelright, 1985). Heizer dan Render (2001) berpendapat bahwa keberhasilan strategi operasi tergantung pada konsistensinya dengan lingkungan persaingan, strategi perusahaan, dan daur hidup produk yang disebut sebagai prakondisi.

Model ini dikembangkan untuk menguji pengaruh lingkungan bisnis dalam menentukan pilihan prioritas kompetitif perusahaan atau strategi operasi. Studi empiris dalam strategi operasi membuktikan bahwa pilihan strategi operasi perusahaan terkait dengan faktor lingkungan bisnis. Lingkungan bisnis dipandang sebagai trend perubahan yang dapat menciptakan kesempatan dan tantangan bagi organisasi (Swamidass dan Newel, 1987).

Dalam menghadapi persaingan industri yang semakin ketat akibat perubahan-perubahan lingkungan bisnis memaksa pelaku-pelaku industri, baik sektor industri manufaktur maupun industri jasa, untuk memikirkan cara-cara baru dalam memenangkan persaingan Vananay dan
Zulkarnain (2006). Bukti empiris telah membuktikan keberadaan dan keterkaitan antara lingkungan dan strategi operasi (Ward et. al., 1995; Badri and Davis, 2000).

Model ini dikembangkan berdasarkan hasil studi empiris beberapa peneliti yang melakukan penelitian pada setting lingkungan bisnis yang berbeda-beda. Dalam model ini ditetapkan adanya hubungan eksplisit antara lingkungan dan strategi operasi. Lingkungan bisnis diwakili oleh empat dimensi yaitu biaya bisnis, ketersediaan tenaga kerja, tingkat persaingan, dan dinamisme pasar. Sedangkan dimensi biaya, kualitas, fleksibilitas dan pengiriman mewakili prioritas kompetitif dalam strategi operasi. Penelitian-penelitian yang menyatakan bahwa lingkungan berpengaruh terhadap strategi operasi antara lain: Swamidass and Newel (1987), Ward et. al., (1995), Badri et. al., (2000), Ward and Duray (2000) dan Amaoko and Gyampah (2003).

Model ini juga digunakan oleh Ellitan (2001) dengan karakteristik lingkungan dan dimensi strategi operasi yang sama dan diuji secara empiris pada perusahaan manufaktur skala menengah besar di Jawa Timur. Hal ini sesuai dengan hasil penelitian Anatan (2006) dan penelitian Vananay dan Zulkarnain (2006) yang mengambil setting perusahaan manufaktur skala besar di Indonesia. Berdasarkan penelitianpenelitian terdahulu tersebut dapat diajukan hipotesis-hipotesis sebagai berikut:

$\mathrm{H}_{1}$ : Faktor-faktor lingkungan bisnis berpengaruh terhadap strategi biaya.

$\mathrm{H}_{1 \mathrm{a}}$ : Biaya bisnis berpengaruh terhadap strategi biaya.

$\mathrm{H}_{1 \mathrm{~b}}$ : Ketersediaan tenaga kerja berpengaruh terhadap strategi biaya

$\mathrm{H}_{1 \mathrm{c}}$ : Tingkat persaingan berpengaruh terhadap strategi biaya.

$\mathrm{H}_{1 \mathrm{~d}}$ : Dinamisme pasar berpengaruh terhadap strategi biaya. 
$\mathrm{H}_{2}$ : Faktor-faktor lingkungan bisnis berpengaruh terhadap strategi kualitas

$\mathrm{H}_{2 \mathrm{a}}$ : Biaya bisnis berpengaruh terhadap strategi kualitas

$\mathrm{H}_{2 \mathrm{~b}}$ : Ketersediaan tenaga kerja berpengaruh terhadap strategi kualitas

$\mathrm{H}_{2 \mathrm{c}}$ : Tingkat persaingan berpengaruh terhadap strategi kualitas

$\mathrm{H}_{2 \mathrm{~d}}$ : Dinamisme pasar berpengaruh terhadap strategi kualitas

$\mathrm{H}_{3}$ : Faktor-faktor lingkungan bisnis berpengaruh terhadap strategi pengiriman

$\mathrm{H}_{3 \mathrm{a}}$ : Biaya bisnis berpengaruh terhadap strategi pengiriman

$\mathrm{H}_{3 \mathrm{~b}}$ : Ketersediaan tenaga kerja berpengaruh terhadap strategi pengiriman

$\mathrm{H}_{3 \mathrm{c}}$ : Tingkat persaingan berpengaruh terhadap strategi pengiriman

$\mathrm{H}_{3 \mathrm{~d}}$ : Dinamisme pasar berpengaruh terhadap strategi pengiriman

$\mathrm{H}_{4}$ : Faktor-faktor lingkungan bisnis berpengaruh terhadap strategi fleksibilitas

$\mathrm{H}_{4 \mathrm{a}}$ : Biaya bisnis berpengaruh terhadap strategi fleksibilitas

$\mathrm{H}_{4 \mathrm{~b}}$ : Ketersediaan tenaga kerja berpengaruh terhadap strategi fleksibilitas

$\mathrm{H}_{4 \mathrm{c}}$ : Tingkat persaingan berpengaruh terhadap strategi fleksibilitas

$\mathrm{H}_{4 \mathrm{~d}}$ : Dinamisme pasar berpengaruh terhadap strategi fleksibilitas

Swamidass dan Newel (1987) dan Badri et. al., (2000) mengungkapkan adanya hubungan yang signifikan antara strategi operasi dan kinerja perusahaan serta menemukan fakta bahwa penetapan strategi yang tepat bisa meningkatkan kinerja perusahaan. Strategi operasi merupakan senjata manufaktur yang efektif yang memungkinkan fungsi manufaktur untuk memberikan kontribusi dalam meningkatkan kinerja perusahaan dalam merespon perubahan dan ketidakpastian lingkungan bisnis (Wheelwright, 1984; Leong et al., 1990; Roth dan de valde, 1991; Bourgess et. al., 1998; dan Boyer \& Lewis, 2002).

Ellitan (2001) dalam penelitiannya pada perusahaan manufaktur menengah besar di Jawa Timur menemukan adanya pengaruh strategi biaya, kualitas, fleksibilitas, dan pengiriman terhadap kinerja perusahaan. Pengujian yang sama dilakukan Ghofar (2004) dengan mengambil sampel perusahaan manufaktur menengah besar di Daerah Istimewa Yogyakarta, hasil penelitian menunjukan bahwa terdapat pengaruh pilihan strategi operasi terhadap kinerja perusahaan. Sedangkan Anatan (2006) dengan melakukan pengujian empiris pada perusahaan skala besar di Indonesia menemukan bahwa strategi operasi mempunyai pengaruh yang signifikan terhadap peningkatan kinerja perusahaan. Berdasarkan temuan penelitian terdahulu tersebut dapat diajukan hipotesis-hipotesis sebagi berikut:

$\mathrm{H}_{5}$ : Strategi biaya berpengaruh terhadap kinerja perusahaan.

$\mathrm{H}_{6}$ : Strategi kualitas berpengaruh terhadap kinerja perusahaan

$\mathrm{H}_{7}$ : Strategi pengiriman berpengaruh terhadap kinerja perusahaan

$\mathrm{H}_{8}$ : Strategi fleksibilitas berpengaruh terhadap kinerja perusahaan

\section{Metodologi Penelitian}

Penelitian ini bersifat penjelasan ( $e x$ planatory research), artinya penelitian ini akan menjelaskan secara mendalam hubungan sebab akibat antar variabel penelitian tentang sesuatu hal (Coppper, 2005; Achmad, 2003). Penelitian eksplanatori mengacu pada teori atau hipotesis yang akan diuji sebagai penyebab terjadinya suatu fenomena. Metode penelitian yang digunakan adalah metode survei yaitu suatu metode yang menggunakan pengumpulan data 
utamanya dengan kuisioner dari sampel terpilih (Zikmund, 2000; Sekaran, 2003).

Populasi penelitian ini adalah seluruh perusahaan manufaktur skala menengah besar di Tasikmalaya. Sementara populasi sasaran yang digunakan adalah perusahaan yang telah mempunyai departemen atau tim perencanaan strategik dan/atau melaksanakan perencanaan strategik dalam pengambilan keputusan strategik. Berdasarkan data dari Dinas Perindustrian dan Perdagangan Kota Tasikmalaya Tahun 2008 tercatat 192 perusahaan.

Mengingat metoda analisis data dalam penelitian ini menggunakan Structural Equation model (SEM), yang dioperasikan melalui program AMOS maka ukuran sampel penelitian ini diambil sejumlah 110 perusahaan. Alasan ditetapkannya sampel sebanyak 110 perusahaan mengacu pada saran Hair, Anderson, Tatham, and Black (1998) yang menyatakan bahwa syarat penggunaan metode Stuctural Equation Modeling (SEM) dibutuhkan sampel minimum sebanyak 100 perusahaan.

Metode penarikan sampel yang dipakai yaitu stratified sampling method. Tekniknya adalah setelah menetapkan jumlah sampel yang diperlukan (110 perusahaan), kemudian diambil secara random tiap-tiap kelompok perusahaan secara proposional yaitu, sesuai dengan jumlah perusahaan dalam kelompok dibagi dengan jumlah populasi keseluruhan dikali 110 .

Pengujian hipotesis yang diajukan digunakan alat uji Model Persamaan Struktural (Structural Equation Model SEM) dengan menggunakan paket program AMOS 6 (Analysis of Moment Structure) dan SPSS versi 13.0. Penggunaan SEM memungkinkan peneliti untuk menguji validitas dan reliabilitas instrumen penelitian, mengkonfirmasi ketepatan model sekaligus menguji pengaruh suatu variabel terhadap variabel lain. SEM dapat menguji secara bersama-sama (Bohlen, dalam Ghozali dan Fuad, 2005).

\section{HASIL PENELITIAN DAN PEMBAHASAN \\ Profil Responden}

Perusahaan yang telah berpartisipasi dalam penelitian ini merupakan perusahaan manufaktur skala menengah dan besar di Tasikmalaya yang berjumlah 110 perusahaan. Berdasarkan data sebagian besar perusahaan telah beroperasi selama 10 - 20 tahun (30,9\%). Berdasarkan bidang usaha sebagian besar perusahaan bergerak dalam bidang konveksi dan bordir (40,9\%), sedangkan dilihat kepemilikannya ternyata keseluruhan perusahaan merupakan milik pengusaha lokal (100\%). Berdasarkan jumlah tenaga kerja tetap yang dimiliki terdapat 90 perusahaan yang termasuk dalam kelompok perusahaan berskala menengah sedangkan perusahaan yang termasuk dalam kelompok perusahaan berskala besar sebanyak 11 perusahaan.

\section{Deskriptif Variabel}

Berdasarkan Tabel 1 dibawah dapat disimpulkan bahwa indikator tajamnya persaingan di pasar lokal merupakan hal yang paling menjadi perhatian bagi perusahaan manufaktur skala menengah dan besar di Tasikmalaya. Hal ini ditunjukkan oleh skor yang paling tinggi diantara indikator-indikator yang lain dalam variabel lingkungan bisnis. Perubahan selera konsumen yang cepat menempati peringkat kedua, sedangkan peningkatan biaya bahan baku menempati peringkat ketiga. 
Tabel 1. Deskripsi Variabel Lingkungan Bisnis

\begin{tabular}{lccc}
\hline \multicolumn{1}{c}{ Variabel Lingkungan Bisnis } & Rata-rata & Standar deviasi & Ranking \\
\hline BIAYA BISNIS & & & \\
Peningkatan biaya tenaga kerja & 7.12 & 2.200 & 6 \\
Peningkatan biaya bahan baku & 7.57 & 2.224 & 3 \\
Peningkatan biaya komunikasi & 6.37 & 2.802 & 10 \\
Peningkatan biaya pengangkutan & 6.32 & 2.563 & 12 \\
KETERSEDIAAN TENAGA KERJA & & & \\
Keterbatasan staf manajerial & 5.49 & 2.857 & 16 \\
Keterbatasan tenaga ahli ( teknisi) & 6.61 & 2.713 & 9 \\
Keterbatasan staf administrasi & 5.63 & 2.598 & 15 \\
Keterbatasan karyawan produksi & 7.47 & 2.200 & 4 \\
TINGKAT PERSAINGAN & & & \\
Tajamnya persaingan di pasar lokal & 8.26 & 1.506 & 1 \\
Margin profit yang rendah & 7.26 & 2.187 & 5 \\
Ketidakandalan kualitas pemasok & 6.98 & 2.431 & 7 \\
Penurunan permintaan & 6.75 & 2.814 & 8 \\
DINAMISME PASAR & & & \\
Keusangan produk dibanding pesaing & 6.35 & 2.579 & 11 \\
Inovasi proses produksi baru yang rendah & 6.07 & 2.558 & 13 \\
Perubahan selera konsumen yang cepat & 7.92 & 2.159 & 2 \\
Inovasi produk baru yang rendah & 5.96 & 2.460 & 14 \\
\hline Sumber: Data diolah & & & \\
\hline
\end{tabular}

Sumber: Data diolah

Tabel 2. Deskripsi Variabel Strategi Operasi

\begin{tabular}{lccc}
\hline Variabel Strategi Operasi & Rata-rata & $\begin{array}{c}\text { Standar } \\
\text { deviasi }\end{array}$ & Rank \\
\hline STRATEGI BIAYA & & & \\
Menurunkan biaya per unit & 6.69 & 2.241 & 13 \\
Menurunkan biaya bahan baku & 7.11 & 2.074 & 11 \\
Menurunkan biaya overhead & 7.22 & 1.879 & 10 \\
Menurunkan biaya persediaan & 6.78 & 2.203 & 12 \\
STRATEGI KUALITAS & & & \\
Menurunkan tingkat kecacatan produk & 8.05 & 2.173 & 7 \\
Memperbaiki kualitas pemasok/vendor & 8.65 & 1.344 & 1 \\
Memperbaiki keandalan/ kinerja produk & 8.65 & 1.639 & 2 \\
Menambah perolehan sertifikasi kualitas & 7.52 & 2.380 & 9 \\
STRATEGI PENGIRIMAN & & & \\
Memperbaiki layanan pra-jual & 8.50 & 1.691 & 3 \\
Memperbaiki pelayanan pasca jual & 8.40 & 1.534 & 6 \\
Meningkatkan keandalan pengiriman & 8.41 & 1.504 & 5 \\
Meningkatkan kecepatan pengiriman & 8.44 & 1.611 & 4 \\
STRATEGI FLEKSIBILITAS & & & \\
Meningkatkan model atau variasi produk & 7.99 & 2.568 & 8 \\
Menurunkan tenggang waktu pabrikasi & 6.15 & 2.449 & 15 \\
Menurunkan tenggang waktu pembelian bahan baku & 6.61 & 2.655 & 14 \\
Menurunkan waktu set up mesin & 5.48 & 2.739 & 16 \\
\hline Suber: Data diolah
\end{tabular}

Sumber: Data diolah 
Berdasarkan Tabel 2 di atas dapat disimpulkan bahwa prioritas strategi operasi yang lebih ditekankan pada perusahaan manufaktur skala menengah dan besar di Tasikmalaya adalah strategi pengiriman, strategi kualitas, strategi biaya dan terakhir adalah strategi fleksibilitas. Lima pilihan strategi yang dijalankan oleh perusahaan manufaktur di Tasikmalaya meliputi memperbaiki kualitas pemasok/vendor, memperbaiki keandalan/kinerja produk, meningkatkan layanan pra-jual, meningkatkan kecepatan pengiriman, dan meningkatkan keandalan pengiriman.

Tabel 3 menunjukkan bahwa rata-rata kinerja perusahaan manufaktur skala menengah dan besar di Tasikmalaya adalah baik dari berbagai perfektif. Kinerja dalam peningkatan kualitas produk merupakan aspek kinerja yang mempunyai pencapaian yang paling tinggi. Dimensi yang paling dominan berperan dalam menjelaskan kinerja perusahaan adalah persfektif bisnis internal. Hal ini menunjukkan bahwa para perencana strategi berusaha melakukan peningkatan kinerja perusahaan secara keseluruhan sebaiknya, dimulai dengan adanya peningkatan perfektif bisnis internal. Dalam perspektif bisnis internal dimulai dengan meningkatkan inovasi produk dan peningkatan kualitas produk yang selanjutnya akan meningkatkan kepuasan konsumen dan peningkatan jumlah konsumen baru yang akhirnya akan meningkatkan kinerja keuangan.

Tabel 3. Deskripsi Variabel Kinerja Perusahaan

\begin{tabular}{|c|c|c|c|}
\hline Variabel Kinerja Perusahaan & Rata-rata & Standar deviasi & Rank \\
\hline \multicolumn{4}{|l|}{ Persfektif Keuangan } \\
\hline Return on asset (ROA) & 8.16 & 1.499 & 4,5 \\
\hline \multicolumn{4}{|l|}{ Persfektif Pelanggan } \\
\hline Kepuasan pelanggan & 8.91 & 1.121 & 2 \\
\hline Perolehan pelanggan baru & 8.16 & 1.565 & 4,5 \\
\hline \multicolumn{4}{|l|}{ Persfektif Bisnis Internal } \\
\hline Produk baru yang dihasilkan & 8.45 & 1.178 & 3 \\
\hline Peningkatan kualitas produk & 9.07 & .896 & 1 \\
\hline \multicolumn{4}{|l|}{$\begin{array}{l}\text { Persfektif pembelajaran dan } \\
\text { pertumbuhan }\end{array}$} \\
\hline Pengembangan kemampuan pegawai & 7.99 & 1.437 & 7 \\
\hline Peningkatan pemberdayaan pegawai & 8.00 & 1.327 & 6 \\
\hline
\end{tabular}

Sumber: Data diolah 


\section{Uji Kesesuaian Model}

Teknik SEM keseluruhan digunakan untuk menguji model kausalitas yang telah dinyatakan sebelumnya dalam berbagai hubungan sebab akibat (kausal model). Melalui analisis SEM akan terlihat ada tidaknya kesesuaian model dan hubungan kausalitas yang dibangun dalam model uji.

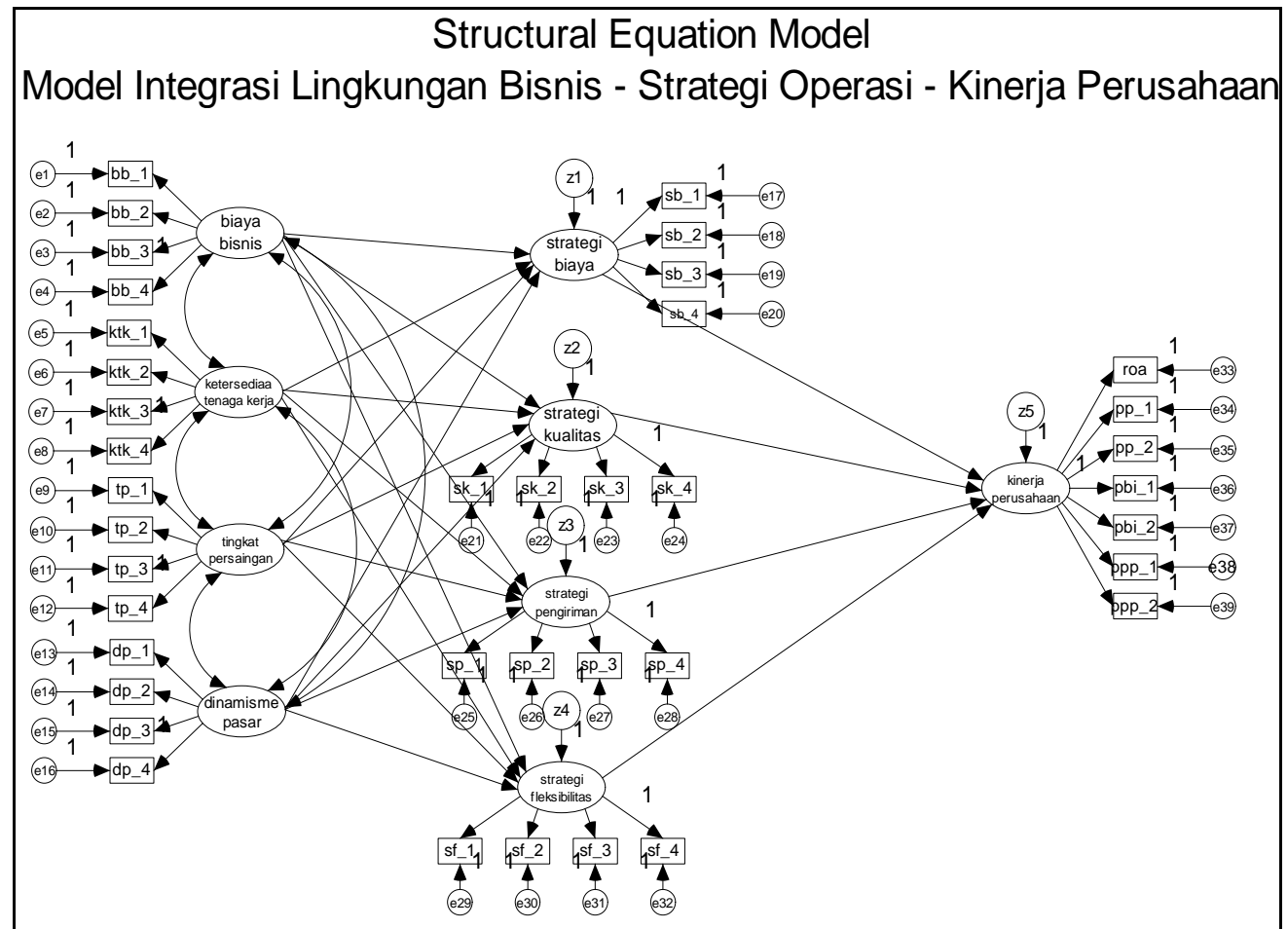

Gambar 3: Path Diagram Penelitian

Tabel 4: Hasil Pengujian Model Integrasi Lingkungan Bisnis - Strategi Operasi - Kinerja Perusahaan pada kriteria Goodness-of Fit Index

\begin{tabular}{lccc}
\hline \multicolumn{1}{c}{ goodness of fit Index } & Cut of Rate & Hasil analisis & Evaluasi Model \\
\hline Chi Square & Kecil & 330,917 & Kurang Baik \\
Signifikansi & $\geq 0,05$ & 0,074 & Baik \\
CMIN/DF & $\leq 2,00$ & 1,122 & Baik \\
GFI & $\geq 0,90$ & 0,824 & Kurang Baik \\
TLI & $\geq 0,95$ & 0,957 & Baik \\
CFI & $\geq 0,95$ & 0,964 & Baik \\
RMSEA & $\leq 0,08$ & 0,034 & Baik \\
\hline
\end{tabular}

Sumber: Output AMOS diolah 
Berdasarkan 7 parameter nilai goodness of fit index hanya 2 parameter yang tidak memenuhi syarat yaitu chi square dan Goodness of Fit Index (GFI). Namun demikian, secara keseluruhan sudah dapat dikatakan bahwa model SEM secara keseluruhan sudah fit (ada kesesuaian antara model dengan data). Analisis SEM menunjukan bahwa seluruh indikator pembentuk konstruk seluruh variabel dalam penelitian dinyatakan signifikan karena memiliki propabilitas error yang lebih kecil dari 0,05 .

\section{Pengujian Hipotesis dan Hubungan Kausal}

Besarnya pengaruh dari variabel variabel yang diteliti yaitu hasil pengujian hipotesis antar variabel selengkapnya dapat dilihat pada Tabel 5 .

Tabel 5: Hasil Pengujian Hipotesis

\begin{tabular}{|c|c|c|c|c|c|}
\hline Variabel & Estimate & $\begin{array}{c}\text { Standar } \\
\text { error }\end{array}$ & $\begin{array}{c}\text { Critical } \\
\text { Ratio }\end{array}$ & Probability & Keterangan \\
\hline \multicolumn{6}{|c|}{ Pengaruh Lingkungan Bisnis terhadap Strategi Biaya } \\
\hline $\mathrm{Y} 1-\mathrm{X} 1$ & 0,320 & 0,129 & 2,487 & 0,013 & signifikan \\
\hline $\mathrm{Y} 1-\mathrm{X} 2$ & 0,287 & 0,200 & 1,437 & 0,151 & tidak signifikan \\
\hline $\mathrm{Y} 1-\mathrm{X} 3$ & 0,356 & 0,131 & 2,713 & 0,007 & Signifikan \\
\hline $\mathrm{Y} 1-\mathrm{X} 4$ & 0,036 & 0,202 & $-0,179$ & 0,858 & tidak signifikan \\
\hline \multicolumn{6}{|c|}{ Pengaruh Lingkungan Bisnis terhadap Strategi Kualitas } \\
\hline $\mathrm{Y} 2-\mathrm{X} 1$ & 0,217 & 0,074 & 2,917 & 0,004 & signifikan \\
\hline $\mathrm{Y} 2-\mathrm{X} 2$ & 0,750 & 0,240 & 3,124 & 0,002 & Signifikan \\
\hline $\mathrm{Y} 2-\mathrm{X} 3$ & $-0,016$ & 0,101 & $-1,158$ & 0,875 & tidak signifikan \\
\hline $\mathrm{Y} 2-\mathrm{X} 4$ & 0,464 & 0,185 & 2,503 & 0,012 & Signifikan \\
\hline \multicolumn{6}{|c|}{ Pengaruh Lingkungan Bisnis terhadap Strategi Pengiriman } \\
\hline $\mathrm{Y} 3-\mathrm{X} 1$ & $-0,035$ & 0,099 & $-0,355$ & 0,722 & tidak signifikan \\
\hline $\mathrm{Y} 3-\mathrm{X} 2$ & 0,394 & 0,174 & 2,262 & 0,024 & Signifikan \\
\hline $\mathrm{Y} 3-\mathrm{X} 3$ & 0,236 & 0,102 & 2,309 & 0,021 & Signifikan \\
\hline $\mathrm{Y} 3-\mathrm{X} 4$ & 0,173 & 0,169 & 1,020 & 0,308 & tidak signifikan \\
\hline \multicolumn{6}{|c|}{ Pengaruh Lingkungan Bisnis terhadap Strategi Fleksibilitas } \\
\hline $\mathrm{Y} 4-\mathrm{X} 1$ & 0,256 & 0,118 & 2,166 & 0,030 & Signifikan \\
\hline $\mathrm{Y} 4-\mathrm{X} 2$ & 0,766 & 0,298 & 2,570 & 0,010 & Signifikan \\
\hline $\mathrm{Y} 4-\mathrm{X} 3$ & 0,307 & 0,181 & 1,701 & 0,089 & tidak signifikan \\
\hline $\mathrm{Y} 4-\mathrm{X} 4$ & 0,068 & 0,237 & 0,288 & 0,774 & tidak signifikan \\
\hline \multicolumn{6}{|c|}{ Pengaruh Strategi Operasi terhadap Kinerja Perusahaan } \\
\hline Y5 - Y1 & 0,316 & 0,130 & 2,431 & 0,015 & Signifikan \\
\hline Y5 - Y2 & 0,170 & 0,047 & 3,617 & 0,034 & Signifikan \\
\hline $\mathrm{Y} 5-\mathrm{Y} 3$ & 1,100 & 0,339 & 3,245 & 0,049 & Signifikan \\
\hline Y5 - Y4 & 0,248 & 0,136 & 1,824 & 0,2651 & tidak signifikan \\
\hline
\end{tabular}

Sumber: Output AMOS diolah 
Tabel 5 menunjukkan bahwa:

Pengujian Hipotesis 1: pengaruh faktorfaktor lingkungan bisnis terhadap pilihan strategi biaya. Dari faktor-faktor lingkungan bisnis ternyata Biaya bisnis dan tingkat persaingan berpengaruh terhadap strategi biaya sedangkan ketersediaan tenaga kerja dan dinamisme pasar tidak berpengaruh.

Pengujian Hipotesis 2: pengaruh faktor-faktor lingkungan bisnis terhadap pilihan strategi kualitas. Hanya tingkat persaingan saja yang tidak berpengaruh terhadap strategi kualitas, sedangkan ketiga faktor yang lain dari lingkungan bisnis berpengaruh.

Pengujian Hipotesis 3: pengaruh faktor-faktor lingkungan bisnis terhadap pilihan strategi pengiriman. Ketersediaan tenaga kerja dan tingkat persaingan berpengaruh terhadap strategi pengiriman sedangkan biaya bisnis dan dinamisme pasar tidak berpengaruh.

Pengujian Hipotesis 4: pengaruh faktor-faktor lingkungan bisnis terhadap pilihan strategi fleksibilitas. Biaya bisnis dan ketersediaan tenaga kerja berpengaruh terhadap strategi flesibilitas sedangkan tingkat persaingan dan dinamisme pasar tidak berpengaruh.

Pengujian Hipotesis 5: pengaruh pilihan strategi biaya terhadap kinerja perusahaan. Pilihan strategi biaya berpengaruh terhadap kinerja perusahaan yang diukur dengan balance scorecard.

Pengujian Hipotesis 6: pengaruh pilihan strategi kualitas terhadap kinerja perusahaan. Pilihan strategi kualitas berpengaruh terhadap kinerja perusahaan yang diukur dengan balance scorecard.

Pengujian Hipotesis 7: pengaruh pilihan strategi pengiriman terhadap kinerja perusahaan. Pilihan strategi pengiriman berpengaruh terhadap kinerja perusahaan yang diukur dengan balance scorecard

Pengujian Hipotesis 8: pengaruh pilihan strategi fleksibilitas terhadap kinerja perusahaan. Pilihan strategi fleksibilitas tidak berpengaruh terhadap kinerja perusahaan yang diukur dengan balance scorecard

\section{Pembahasan}

Pada bagian ini akan dibahas analisis terhadap hasil penelitian yang telah dijelaskan pada bagian sebelumnya. Pembahasan dilakukan berdasarkan pada temuan empiris maupun teori dan penelitian-penelitian sebelumnya yang relevan dengan penelitian.

\section{Pengaruh Lingkungan Bisnis Terhadap Strategi Operasi}

Hasil penelitian menunjukkan bahwa faktor-faktor lingkungan bisnis mempengaruhi pilihan strategi operasi. Kesimpulan penting yang dapat diambil dari pengujian hipotesis adalah bahwa pertimbangan lingkungan bisnis memainkan peran yang signifikan dalam menentukan pilihan strategi operasi. Oleh karena itu, peneliti dibidang strategi operasi tidak seharusnya mengabaikan efek lingkungan dalam penelitian terkait dengan manajemen strategi.

1) Faktor lingkungan bisnis yang mempengaruhi pilihan strategi biaya adalah biaya bisnis dan tingkat persaingan. Hal ini memberikan makna bahwa para pelaku usaha yang memilih strategi biaya sebagai prioritas utamanya harus memberikan konsentrasi yang lebih pada biaya bisnis dan tingkat persaingan agar strategi operasi yang dipilihnya dapat memberikan peningkatan pada kinerja perusahaan.

2) Hampir semua faktor-faktor lingkungan bisnis berpengaruh terhadap pilihan strategi kualitas kecuali tingkat persaingan. Temuan ini menunjukkan bahwa efektifitas pelaksanaan strategi kualitas akan sangat tergantung dari perhatian perusahaan terhadap tiga faktor lingkungan bisnis yaitu biaya bisnis, ketersediaan tenaga kerja dan dinamisme pasar. Memperhitungkan 
ketiga faktor lingkungan tersebut dalam penyusunan strategi kualitas akan meningkatkan kinerja perusahaan.

3) Ketersediaan tenaga kerja dan tingkat persaingan memegang peranan penting dalam pilihan strategi pengiriman. Strategi pengiriman membutuhkan tenaga kerja yang kompeten dan mampu malaksanakan pelayanan pra penjualan dan pasca penjualan. Selain itu para pelaku usaha juga harus memperhatikan tingkat persaingan yang tajam agar pelaksanaan strategi pengiriman mampu memenuhi harapan para konsumen yang akhirnya mampu meningkatkan kinerja perusahaan secara keseluruhan

4) Strategi Fleksibilitas dipengaruhi hampir semua faktor lingkungan bisnis kecuali dinamisme pasar. Hal ini mewajibkan para pelaku usaha untuk memberikan perhatian yang lebih pada tiga faktor lingkungan bisnis yaitu biaya bisnis, ketersediaan tenaga kerja dan tingkat persaingan agar pelaksanaan strategi fleksibilitas yang dipilih mampu memberikan kontribusi pada peningkatan kinerja perusahaan.

Berdasarkan hasil pengujian statistik diskriptif bahwa variabel tingkat persaingan terkait dengan tajamnya persaingan di pasar lokal merupakan faktor yang mendapat perhatian terbesar dibandingkan faktor lingkungan yang lainnya. Faktor lain yang mendapat perhatian penting adalah peningkatan biaya-biaya bisnis serta dinamisme pasar. Sedangkan faktor dinamisme pasar mendapat perhatian atau konsentrasi lebih rendah dibandingkan faktor-faktor lain.

Penemuan ini konsisten dengan penelitian yang dilakukan oleh Amaoko (2003) dengan setting penelitian di Ghana sebagai salah satu negara industrial baru (newly industrial countries). Perusahaanperusahaan manufaktur di Tasikmalaya lebih cenderung memperhatikan faktor biaya bisnis, tajamnya persaingan, dan dinamisme pasar. Hal ini dikarenakan perusahaanperusahaan manufaktur di Tasikmalaya dihadapkan pada situasi lingkungan bisnis, khususnya kondisi perekonomian makro yang cenderung tidak stabil yang diindikasikan oleh peningkatan biaya-biaya usaha.

Perusahaan juga dihadapkan pada makin kritisnya konsumen untuk mendapatkan produk atau jasa dengan kualitas tinggi dan waktu tunggu yang pendek. Pada saat yang bersamaan perusahaan tidak dapat mencegah atau mengontrol meningkatnya persaingan bisnis sebagai akibat dari bertambahnya perusahaan sejenis dalam industri. Dalam kondisi tersebut, perusahaan manufaktur di Tasikmalaya cenderung untuk memberikan perhatian tinggi pada kondisi persaingan dan biaya bisnis.

Meskipun persepsi tentang tajamnya persaingan merupakan salah satu faktor yang mendapat perhatian terbesar dari perusahaan, tetapi persaingan bukan merupakan faktor yang paling berpengaruh terhadap semuan pilihan strategi operasi. Hasil analisa menunjukkan bahwa tingkat persaingan bisnis hanya berpengaruh pada pilihan strategi biaya dan strategi pengiriman. Perusahaan manufaktur di Tasikmalaya tidak memperhatikan kapabilitas perusahaan untuk bersaing dalam pasar luar negeri, sebaliknya mereka berkonsentrasi pada tajamnya persaingan dalam pasar lokal dan kemampuan untuk memenuhi standar kualitas. Untuk menunjukkan tingkat konsentrasi pada tajamnya persaingan, perusahaan lebih menekankan bagaimana menghasilkan produk yang sesuai dengan kebutuhan dan keinginan konsumen melalui peningkatan model dan variasi produk, serta pengembangan produk baru.

Biaya bisnis merupakan faktor lingkungan yang paling banyak memberikan kontribusi atau pengaruh pada keputusan pilihan strategi operasi. Tingkat konsentrasi perusahaan yang tinggi pada biaya bisnis 
diindikasikan dengan tingkat konsentrasi perusahaan yang besar pada peningkatan biaya material atau bahan baku, tenaga kerja, dan pengangkutan bahan mentah dan barang jadi, yang ketiganya berperan penting dalam pencapaian kesuksesan aplikasi strategi biaya, strategi kualitas, maupun strategi fleksibilitas yang memfokuskan pengembangan produk dan peningkatan kualitas produk.

Ketersediaan tenaga kerja mempunyai peran yang signifikan dalam aplikasi strategi kualitas, strategi pengiriman dan strategi fleksibilitas. Sedangkan dinamisme pasar hanya berpengaruh terhadap pelaksanaan strategi kualitas. Tingkat konsentrasi perusahaan pada dinamisme pasar yang diindikasikan dengan tingkat konsentrasi perusahaan pada inovasi produk dan proses serta perubahan selera dan kebutuhan pelanggan menjadi bahan pertimbangan penting untuk menetapkan strategi kualitas. Untuk tetap dapat bersaing dalam kondisi lingkungan yang dinamis dan menciptakan loyalitas pelanggan melalui penciptaan nilai dan kepuasan konsumen, peningkatan kualiats produk dan pemberian layanan terbaik bagi konsumen merupakan pilihan strategi yang paling tepat.

\section{Pengaruh Strategi Operasi Terhadap Kinerja Perusahaan}

Hasil penelitian memberikan bukti empiris bahwa pilihan strategi operasi memberikan pengaruh yang signifikan terhadap kinerja perusahaan yang diukur dengan balance scorecard. Hasil penelitian ini konsisten dengan hasil penelitian Ghofar (2004), Ellitan (2001), dan Anatan (2006).

Berdasarkan data statistik diskripstif menunjukan bahwa strategi kualitas merupakan strategi yang paling banyak dipilih oleh perusahaan manufaktur di Tasikmalaya. Hal ini ditunjukkan dengan aplikasi quality control untuk menghasilkan produk yang baik dan sesuai dengan standar, dan menghindari jangan sampai produk cacat sampai ketangan konsumen. Usaha lain dalam mengimplementasikan strategi kualitas banyak perusahaan yang melakukan perjanjian atau kesepakatan dengan para pemasok atau suplier berkaitan dengan pasokan bahan mentah. Hal ini terbukti bahwa berdasarkan pengujian hipotesis terlihat bahwa strategi yang dipilih tersebut berpengaruh dalam meningkatkan kinerja perusahaan tidak hanya pada kinerja keuangan tetapi juga pada peningkatan kinerja yang lain seperti kinerja perspektif pelanggan, kinerja perspektif bisnis internal dan kinerja perspektif pembelajaran dan pertumbuhan.

Strategi pengiriman menempati peringkat kedua sebagai pilihan strategi operasi yang dijalankan oleh perusahaanperusahaan manufaktur skala menengah besar di Tasikmalaya. Strategi ini dijalankan dengan meningkatkan keandalan dalam pengiriman karena selama ini para pelanggan selalu mengharapkan tepat waktu. Layanan pra jual dan pasca jual menjadi strategi andalan yang dijalankan oleh perusahaan. Layanan pra jual dilakukan melalui workshop cara pembuatan produk di mal sehingga para konsumen mengetahui bagaimana cara membuat produk tersebut. Sedangkan layanan pasca jual dilakukan untuk melengkapi kesempurnaan pelaksanaan strategi pengiriman untuk meningkatkan kepercayaan konsumen kepada perusahaan. Strategi pengiriman ternyata terbukti mampu meningkatkan kinerja perusahaan secara keseluruhan hal ini dibuktikan dengan hasil pengujian hipotesis yang menyatakan bahwa strategi pengiriman berpengaruh secara signifikan terhadap kinerja perusahaan.

Strategi biaya diimplementasikan oleh perusahaan manufaktur di Tasikmalaya dengan cara menurunkan biaya. Hal ini dilakukan agar perusahaan mampu menjual produk yang dihasilkannya dengan harga 
yang kompetitif sehingga mampu bersaing dengan para kompetitor. Kerjasama yang dilakukan dengan para suplier mampu menurunkan biaya bahan baku, sedangkan pengaturan persediaan dapat menurunkan biaya persediaan. Usaha yang dilakukan dalam mengimplentasikan pilihan strategi operasi dengan strategi biaya ternyata terbukti mampu meningkatkan kinerja perusahaan yang diukur dengan balance scorecard.

Satu-satunya strategi yang tidak memberikan kontribusi terhadap peningkatan kinerja perusahaan di perusahaanperusahaan manufaktur di Tasikmalaya adalah strategi fleksibilitas. Strategi ini dilaksanakan dengan melakukan penurunan tenggang waktu pabrikasi, set up mesin dan waktu pembelian bahan baku. Strategi fleksibilitas dilaksanakan juga dengan menambah model dan variasi produk yang disesuaikan dengan keinginan konsumen yang berubah begitu cepat. Hal ini membuat strategi fleksibilitas tidak berpengaruh terhadap kinerja perusahaan.

Perusahaan manufaktur di Tasikmalaya dalam menjalankan kegiatan operasinya khususnya kegiatan manufaktur menggunakan skala prioritas dalam mengimplementasikan strategi operasi tersebut. Keempat strategi tersebut sebetulnya dijalankan tetapi pada porsi dan waktu yang tepat sehingga perusahaan perlu memiliki kemampuan scanning lingkungan dengan jeli dan merancang strategi yang tepat sehingga strategi tersebut sesuai (fit) dengan lingkungan bisnis yang sedang dihadapi oleh perusahaan. Pada akhirnya akhirnya strategi tersebut mampu memberikan pengaruh terhadap peningkatan kinerja dalam berbagai perspektif yaitu perspektif keuangan, perspektif pelanggan, perspektif bisnis internal dan perspektif pembelajaran dan pertumbuhan.

\section{PENUTUP Simpulan}

Berdasarkan hasil penelitian dan pembahasan yang telah dipaparkan pada bab sebelumnya, maka penelitian ini dapat disimpulkan sebagai berikut:

a. Lingkungan bisnis memainkan peran signifikan dalam menentukan pilihan strategi operasi sehingga dalam memutuskan prioritas kompetitif perusahaan, pertimbangan lingkungan harus diidentifikasi secara tepat.

b. Kesuksesan perusahaan dalam kondisi lingkungan bisnis yang tidak pasti akan tercapai jika perusahaan mampu memfokuskan pada strategi biaya, strategi kualitas dan strategi pengiriman. Hal ini dikarenakan kesuksesan perusahaan sangat ditentukan oleh kemampuan perusahaan dalam memenuhi kebutuhan dan kepuasan konsumen. Oleh karena itu kemampuan memproduksi produk berkualitas tinggi, kemampuan perusahaan menurunkan biaya produksi serta kemampuan dalam memberikan layanan dan pengiriman tepat waktu merupakan kunci kesuksesan perusahaan kesuksesan perusahaan dalam persaingan bisnis.

\section{Implikasi}

a. Secara teoritis studi ini mendukung model strategi operasi yang digunakan sebagai dasar teori mengenai model integrasi lingkungan bisnis, strategi operasi dan kinerja perusahaan. Temuan studi ini menambah literatur mengenai strategi operasi terutama di negara berkembang khususnya di Indonesia.

b. Secara khusus hasil penelitian ini diharapkan membantu para pelaku usaha di Tasikmalaya untuk dapat selalu melakukan pengamatan terhadap lingkungan bisnis sehingga mampu mengidentifikasinya serta mampu membuat rencana strategi operasi dengan baik 
yang diharapkan memberikan peningkatan terhadap kinerja perusahaan.

\section{Saran}

Beberapa saran peneliti untuk penelitian-penelitian yang akan datang untuk memperdalam studi tentang strategi operasi meliputi:

a. Penelitian selanjutnya perlu memasukan variabel kontrol seperti ukuran atau skala perusahaan untuk melihat perbedaan persepsi perusahaan antara perusahaan besar, menengah dan kecil dalam merespon lingkungan bisnis dan pengaruhnya terhadap pilhan strategi operasi dan kinerjan perusahaan.

b. Untuk mengurangi monoresponse bias yang disebabkan bias persepsi responden, peneliti yang akan datang sebaiknya menggunakan multiple respondent.

\section{DAFTAR PUSTAKA}

Amaoko, K., Gyampah, \& Boye, S.S. (2001). Operation strategy in an emerging economy: the case of Ghanian manufacturing industry, Journal of Operation Management, $19,59-79$

Amaoko, K.. (2003). The relationship among selected business environment factor and manufacturing strategy: insight from an emerging economy. Omega, 31, $287-301$.

Badan Pusat Statistik Kabupaten Tasikmalaya. (2007). Statistik Industri Besar dan Sedang Kabupaten Tasikmalaya.

Badan Pusat Statistik Kota Tasikmalaya. (2007). Statistik Industri Besar dan Sedang Kota Tasikmalaya.

Badri, M.A., \& Davis, D. (2000). Operation strategy, environment uncertainty, and performance: a path analytic model of industries in developing country, Omega, International Journal of Management Science, 28, $155-173$

Bourgeois, L.J. (1980). Strategy and environment: a conceptual integration. Academy of Management Review, 5 (1), $25-39$.

Braglia, M., Petroni, A. (2000). Toward a taxonomy of search pattern of manufacturing flexibility in small and medium sized firm. Omega, 28, 195 213.

Burgess, T.F. Gules, H.K. Gupta, J.N.D., \& Tekin. (1998). Competitive priorities, process innovations and time based competition in the manufacturing sector of industrializing economies: the case of Turky, Benchmarking for Quality Management and Technology, 5 (4), 304 - 316.

Cao, Q. and Schniederjans, M. J. (2004). Empirical study of the relationship between operations strategy and information system strategyc orientation in an e-commerce environment. International Journal of Production Research, 42 (15) 2915 2939.

Cooper, Donald R, Pamela, Schindler. (2005). Strategyc Management of small firm in hoatila and benign environments. Strategic Management Journal, 10, 75 - 87.

Ellitan, Lena. (2000). The effect of manufacturing strategy on firm's performance an initial study from east java. EMPIRIKA

Ellitan, L., \& Anatan, L. (2008). Manajemn Operasi: Konsep dan Aplikasi. Bandung: PT Refika Aditama. 
Elliyanti, Eulis. (1990). Manufacturing 'missing-link' dalam Strategi Perusahaan. Manajemen Usahawan, 19, Januari.

Elwood, Sarin Buffa. (1994). Manajemen Produksi/Operasi Moderen. Jilid I Edisi 7. Jakarta: Erlangga.

Gerwin, D. (1993). Manufacturing flexibility: a strategy perpective. Management Science, 39, 395 - 410.

Hair, J.F., Anderson, R.L. Tatham, dan W. C. Black. (1998). Multivariate Data Analysis, $5^{\text {Th }}$ ed. Upper saddle River, New Jersey: Prentice Hall, Inc.

Heizer, J. \& Render B. (2001). Prinsipprinsip Manajemen Operasi, Edisi Bahasa Indonesia. Penerbit Salemba Empat.

Krawjesky, L.J., \& Ritzman, L.P. (2002). Operation Management: Strategy and analysis. Sixth Edition, Prentice Hall International, Inc.

Leong. G.K., Synder, D.L. \& Ward , P.T. (1990). Research in the process and content of manufacturing strategy. Omega, 28, 109 - 122 .

Muafi. (2008). Model integrasi, konfigurasi, dan kontijensi lingkungan-strategibersaing-kinerja. Manajemen Usahawan Indonesia, 37, $33-41$.

Mudrajat Kuncoro. (2003). Dampak kinerja eksport dan industri terhadap ekonomi Indonesia. Makalah seminar nasional pasca invasi sekutu ke Irak.

Skinner, W. (1969). Manufacturing-missing link in corporate strategy. Havard
Business Review, May - Jun, 136 146.

Smith, M. J., and Reece, J. S. (1999). The Relationship of Strategy, Fit, Productivity, and business performance in a service setting. Journal of Operation Management, 17, 145 161.

Stonebaker, P. \& Leong, G. (1994). Operation Strategy: Focusing Competitive Excellence. Boston, MA: Allyn and Bacon.

Supriyono, R.A. (1999). Manajemen Biaya Suatu Reformasi Pengelolaan Bisnis. Buku 1. Edisi pertama. Yogyakarta: BPFE.

Swamidass, P.M., Newell, W.T. (1987). Manufacturing Strategy, environment uncertainty and performance: a path analytic model. Management Science, 33 (4), 504 - 529.

Flahrety, T. (1996). Global Operation Management. Mc Graw Hill International Editions.

Ward, P. T. and Duray, R. (2000). Manufacturing Startegy in Context: environment, competitive strategy and manufacturing strategy. Journal of operation management, 18, 123 138.

Ward, P.T. Bickford, D.J., Leong, G.K.. (1995). Business environment, operation strategy, and performance: an empirical study of Singapore manufacturers. Journal of Operation Management, 13 (2), 99 - 115. 